\title{
THE VALUES OF PATIENT EDUCATION IN SURAH AR-RAD VERSE 22
}

\author{
Murni Yanto \\ State Islamic Institut of Curup Indonesia \\ Yantomurni65.gmail.com
}

Received: 01-10-2021

Revised: 30-11-2021

Accepted: 28-12-2021

\begin{abstract}
This article is motivated by the importance of patience in carrying out the educational process, in the world of education various problems faced by everyone are a natural thing, education must be carried out with patience because patience is a behavior of trust in Allah SWT. What are the values of patient education in the Qur'an ar-rad verse 22? The hope of this research is to find out; 1) How is the value of patient education in the Qur'an Ar-rad verse 22, 2) The benefits of patient education in the Qur'an ar-rad verse 22,3$)$ The wisdom of patient education in the Qur'an ar-rad verse 22 . The method is used library research that relies on studies and text studies. Where the researchers conducted a series of collection, managing and analyzing data taken from literature data. The data collection technique was through documentation. Based on the research that has been done, it can be concluded as follows: 1) Patience education is a very important role in dealing with problems and one way to get help from Allah SWT. 2) The benefits of patient education are: getting a reward, the heart becomes calm and always in the protection of Allah SWT. 3) The wisdom of patience, namely: making every worship more perfect and able to carry out every command and stay away from its prohibition
\end{abstract}

Keywords: Educational Value, Patience, Al-Quran

\begin{abstract}
Abstrak
Artikel ini di latar belakangi oleh pentingnya kesabaran dalam melaksanakan proses pendidikan, di dalam dunia pendidikan berbagai masalah yang dihadapi oleh setiap orang merupakan suatu bal yang wajar, pendidikan harus dijalankan dengan kesabaran karena kesabaran merupakan prilaku tawakal kepada Allah SWT. Bagaimana nilai-nilai pendidikan sabar dalam Al-Qur'an surat arrad ayat 22? Harapan dari penelitian ini adalab untuk mengetabui 1) Bagaimana nilai pendidikan sabar dalam Al-Qur'an surat ar-rad ayat 22, 2) Manfaat pendidikan sabar dalam Al-Qur'an surat ar-rad ayat 22, 3) Hikmah pendidikan sabar dalam Al-Qur'an surat ar-rad ayat 22. Metode yang digunakan adalah penelitian kepustakaan yang bertumpu pada kajian dan telaah teks. Dimana peneliti melakukan serangkaian pengumpulan, mengelolah dan menganalisis data yang diambil dari data literatur. Adapun teknik pengumpulan data yaitu dengan melalui dokumentasi. Berdasarkan penelitian yang telah dilakukan dapat disimpulkan hal-hal sebagai berikut: 1) Pendidikan sabar merupakan peranan yang sangat penting dalam menghadapi permasalahan dan salah satu cara untuk memperoleh pertolongan dari Allah SWT. 2) Manfaat pendidikan sabar yaitu: mendapatkan pahala, bati menjadi tenang dan selalu dalam lindungan Allab SWT. 3) Hikmah sabar yaitu: menjadikan setiap ibadahnya lebih sempurna serta dapat melaksanakan setiap perintahnya dan menjaubi larangannya.
\end{abstract}

Kata Kunci: Nilai Pendidikan, Sabar, Al-Quran 


\section{INTRODUCTION}

Education comes from the word "educate" then gets the suffix "pean" and according to the Big Indonesian Dictionary, education means the process of changing one's attitude or behavior in maturing humans through teaching and training efforts. ${ }^{1}$ Education is the only way to disseminate knowledge or elevate human dignity and to instill human values. So, it can be said the extent to which a person's success in the field of teaching and in the field of education. ${ }^{2}$ Education is guidance or leadership that is carried out consciously by educators on the physical and spiritual development of educated towards the formation of the main personality. ${ }^{3}$

Education is basically a process of transforming knowledge towards improvement, strengthening and perfecting human potential. In Islam, the goal to be achieved in education is to form Insan Kamil, namely a complete human being who has both intellectual and spiritual intelligence. ${ }^{4}$

In line with the above understanding in Law no. 20 of 2003 concerning the National Education System states the notion of education, education is a conscious and planned effort to create a learning atmosphere and learning process so that students actively develop their potential to have religious spiritual strength, self-control, personality, intelligence, noble character, and skills. needed by himself, society, nation and state..$^{5}$

In its development, the term education means guidance or assistance given intentionally to students by adults. Education is also an effort carried out by a person or group of people to achieve higher education. Education also means a conscious effort made by someone in association with children for physical and spiritual development. ${ }^{6}$

Given the importance of the role of education in carrying out the educational process should have the ability to carry out duties and responsibilities. By having abilities that can help as an educator in developing a goal to be achieved ${ }^{7}$.

In the world of education, various problems faced by every human being are a natural thing. But unpreparedness to face the problems that arise is a very big danger for oneself and for others. Therefore education must be carried out with patience. Because patience is the behavior of intelligent people. In QS. Ar-Rad Verse 22 which reads:

Meaning: "And those who are patient, hoping for the pleasure of their Lord, establish prayer and spend some of the sustenance we have given them secretly or openly, and reject evil with good, those are the ones who will get the final place (the good one). )." (Qs. Ar-Rad Verse 22)

Based on the verse above that how lucky humans have been given by Allah SWT the nature of patience because with patience humans will be able to achieve their goals even though there are many obstacles and obstacles faced. Because the more people who have patience, the closer they will be to Allah SW.

\footnotetext{
${ }^{1}$ Agus Mahfud, Islamic Education (depok: Nadi Pustaka, 2012), 8.

2 Abidin Ibn Rush, Al-Ghazali's Thoughts on Education (Yogyakarta: Student Library, 2009), 55.

${ }^{3}$ Novan Ardy Wijaya, Faith and Taqwa-Based Character Education (Yogyakarta: : Teras, 2012), 81.

4 Zakiah Daradjat, Islamic Education (Jakarta: Bumi Aksara, 1996), 5.

5 Bambang Sudibyo, RI Law No. 20 of 2003 concerning National Education System and RI Government Regulation No. 47 of 2008 concerning Compulsory Education (Bandung: Citra Umbara, 2008), 2.

${ }^{6} \mathrm{Hj}$. Eneng Muslihan, islamic education (Jakarta: Diadit Media, 2011), 2.

7 Mar'atul Azizah dan Miranda Nur Apdila, "Peran Kepala Madrasah Sebagai Supervisor Dalam Peningkatan Kinerja Guru," Chalim Journal of Teaching and Learning (CJoTL) 1, no. 1 (24 Agustus 2021): 73-84; Ahmad Khosyi'in, "Peran Kepemimpinan Kepala Sekolah, Pengambilan Keputusan, Dan Budaya Organisasi Terhadap Disiplin Kerja," Chalim Journal of Teaching and Learning (CJoTL) 1, no. 1 (7 Agustus 2021): 45-55.
} 


\section{METHOD}

In library research, library searches are more than just serving functions. Library research as well as utilizing library resources to obtain research data. ${ }^{8}$ In library research, it is not intended to introduce more broad literature research. First, the characteristics of library research as an autonomous method will be described, then followed by an introduction to the classification system of library collections. ${ }^{9}$

There are at least four main characteristics of library research, namely: The first characteristic, that research deals directly with text (nash) or numerical data, not with direct knowledge from the field or eyewitnesses in the form of events of people or other objects. The second characteristic, library data is ready-made, meaning that researchers do not go anywhere except dealing directly with source materials that are already available in the library. The third characteristic, that generally library data is a secondary source, in the sense that the researcher obtains material from the second hand and not the original data from the first hand in the field. The fourth characteristic is that the condition of library data is not limited by space and time, researchers are dealing with fixed static information. This means that whenever it comes and goes the data will never change because it is already "dead" data stored in written records (text, numbers, images, tape recordings or films).

\section{RESEARCH RESULT}

\section{Definition of Education}

Etymologically, education comes from the Greek Paedagogiek, "Pais" means child, gogos means guidance and "iek" means knowledge. So, etymologically, pedagogy is a science that talks about how to provide guidance to children. Terminologically, education is a process of improving, strengthening and perfecting all human abilities and potentials. Education is also defined as a human endeavor to foster his personality in accordance with the values and culture that exist in society. In Arabic there are several terms that are commonly used in the sense of education. Ta'lim can be used also the word Tarbiyah is used for education. Then the word Ta'dib is used to teach. ${ }^{10}$ In simple terms, education can be interpreted as guidance or conscious leadership by the educator on the physical and spiritual development of the educated towards the formation of the main personality. ${ }^{11}$

Education is a process carried out by each individual to get balance and perfection to form a good personality. With this process, a nation and state will be able to pass on religious values, culture, thoughts and expertise to the next generation in order to make the future life of the nation and state better. ${ }^{12}$

The definition above explains that education is the initial foundation and initial foothold in the process of developing the potential possessed by everyone. For this reason, an effort is needed with the aim of forming an independent person so that he becomes someone who is educated to be useful for the Nation and the State. Education also has a goal to be achieved because in Islam education must be balanced between the life of the world and the hereafter so that every Muslim between men and women has the same obligations and responsibilities in order to study and have the opportunity to get an education.

\footnotetext{
${ }^{8}$ Mestika Zed Zed, Literature Research Methods (Jakarta: Indonesia Obor Foundation, 2008), 1.

${ }^{9}$ Zed, 2.

${ }^{10}$ Hasan Langgulung, Principles of Islamic Education (Jakarta: PT Pustaka Al Husna Baru, 2003), 2-3.

${ }^{11}$ Abbudin Nata, Paradigm of Islamic Education (Jakarta: PT Grasindo, 21), 1.

${ }^{12}$ Nurkholis, "Education in Efforts to Advance Technology," Journal of Education Vol 1, No 1 (2013):
}

25. 
Education is a process of growth and development as a result of individual interaction with the social and physical environment that lasts throughout life since humans are born. ${ }^{13}$ Education plays a role as a process of raising the quality of students' thinking to a better level. Thus, education is tasked with shaping and modifying standard activities that can be useful for activities in society. ${ }^{14}$ Education as guidance or conscious education by educators on the development of students both physically and spiritually towards the formation of the main personality. ${ }^{15}$

Education is a process of activities carried out by humans consciously as an effort to provide programmed learning experiences in the form of formal, non-formal and informal education at school and outside school that lasts a lifetime which aims to improve individual abilities so that in the future they can realize the goals to be achieved.

Education is a process of changing the attitudes and behavior of a person or group of people in an effort to mature humans through teaching, training, processes, actions and ways of educating. ${ }^{16}$

The definition above explains that education is an activity that is carried out regularly and directed in an education system for the unity of various interrelated and related components in order to achieve a goal to be achieved. Education is an activity to develop all the potential and aspects of the human personality that lasts a lifetime throughout human life. Thus education is not just education that takes place in the classroom but it includes all activities that contain elements of developing every potential that a person has anytime and anywhere.

Education is a conscious and planned effort to create a learning atmosphere and learning process so that students actively develop their potential to have religious spiritual strength, self-control, personality, intelligence, noble character, and skills needed by themselves, society, nation and state.

Education has a strategic and urgent value in the formation of a nation. Education also has an effort for the survival of the nation. Because it is through education that the noble values possessed by a nation will be inherited. Because education is very important to realize the desires achieved and requires the transfer of culture and culture. ${ }^{17}$

The role of education in building and maintaining a nation's civilization is very important. This is because education is able to provide the quality of human resources needed for it all so that education is often defined as an effort that is made consciously and has continuous sustainability to form a complete human being physically and spiritually. ${ }^{18}$

In the Qur'an as the main source of Islamic teachings, words or terms with meanings related to education can be found, namely Rabba, Allama and Addaba. ${ }^{19}$ Allah STW says in QS. Al-Alaq verse 5.

Meaning: "He who teaches people what they do not know." (Surat al-Alaq verse 5)

Based on the verse above that education is a process of instilling something into humans which is carried out gradually which is implanted into humans to instill what is called education which refers to the recipient of the process and the content itself.

\footnotetext{
${ }^{13}$ Uyoh Sadulloh, Educational Science Pedagogy (Bandung: AlFABETA, 2011), 25.

${ }^{14}$ Lestari \& Ngatini, Contextual Islamic Education (Yogyakarta: Pustaka Pelajar, 2010), 110.

${ }^{15}$ Syamsul Kurniawan, Philosophy of Islamic Education (malang: Madani, 2017), 6.

${ }^{16}$ Samsul Nizar, Introduction to the Fundamentals of Islamic Education Thought (Jakarta: Gaya Media Pratama, 2001), 92.

${ }^{17}$ Daulay Haydar Putra, Islamic Education in the National Education System in Indonesia (Kencana Prenada Media Group, 2004), 6.

18 Mukani, Dynamics of Islamic Education (Yogyakarta: Madani, 2016), 18.

${ }^{19}$ Achmadi, Ideology of Islamic Education (Yogyakarta: Pustaka Pelajar, 2005), 8.
} 
Education is a very important thing in life and humans have the right to get education and develop their abilities through education because every education possessed by each individual has a different process. The first time we get education in the family, school and community. For this reason, in the world of education, family, school and community are the three centers of education because these three institutions have the same role with the aim of delivering humans to become good individuals.

\section{Educational Goals}

The purpose of education contains a description of the values that are good, noble, appropriate, true and beautiful for life. Therefore, the purpose of education has two functions, namely providing direction to all educational activities and is something that all educational activities want to achieve. ${ }^{20}$ Al-Qabisi's desired educational goal is so that education and teaching can foster children's personal development in accordance with true Islamic values. Al-Qabisi also wants educational goals that lead to children having a skill. ${ }^{21}$ According to AlGhazali, the purpose of education is to become a full-fledged human being who draws closer to Allah SW'T and becomes a full-time human being who aims to get happiness in the world and the hereafter. ${ }^{22}$

Another view also says that the purpose of education is to educate the nation's life, to make people believe, fear Allah SWT, have noble character, have knowledge, skills, physical and spiritual health, are independent and have a sense of responsibility in social life. ${ }^{23}$ With education, it will make a person more inclined to prioritize the formation of good and religious attitudes in the family, school and community environment. With the purpose of education will also experience a change in accordance with human development because education starts from human birth to adulthood.

\section{Education Function}

The function of education for everyone is to develop the abilities and character of each person in the context of the intellectual life of the nation which aims to make a person have potential and become a human being who is faithful, pious, has noble character and is knowledgeable. Based on the explanation above, the function of education is as an effort to develop an ability possessed by everyone to become a better person that is useful for everyone and to instill the skills possessed to become a source of innovation in the surrounding environment. Everyone has a different way of implementing the function of education. However, everyone must aim at one goal, namely intelligent, moral, skilled and being a good citizen and must set a good example to everyone around him.

\section{The Nature of Education}

The essence of education is 4 very basic things, namely as follows: 1) Education is essentially a process of fostering the human mind which is the main potential of humans as thinking creatures. 2) Education is essentially a skill training after humans have obtained adequate knowledge from the results of their thinking. 3) Education is carried out in formal and non-formal institutions as carried out in schools, families and communities. 4) Education aims to create a society that has a high culture and civilization with the main indicators of increasing people's intellectual intelligence, good and authoritative community ethics and morals and the formation of a noble personality. ${ }^{24}$

\footnotetext{
${ }^{20}$ Nizar, Introduction to the Fundamentals of Islamic Education Thought, 37.

${ }^{21}$ Rachman Assegaf, School of Islamic Education Thought (depok: PT Raja Grafindo, 2013), 66.

22 Aas Siti Sholichah, Educational Theories in Islam, No 1, vol. 07 (Jakarta: , Islamic Education, 2017), 31. (2019): 31

${ }^{23}$ Adi Widy, "Functions and Goals of Indonesian Education" Journal of Basic Education Vol 4 No 1

${ }^{24}$ Hasan Basri, Philosophy of Islamic Education (Bandung: Pustaka Setia, 2009), 37.
} 
The essence of education in Islam is an absolute obligation imposed on all Muslims, even the obligation of education or seeking knowledge starts from the baby in the womb until it enters the grave. A pregnant mother is encouraged to multiply worship, read the Koran and dhikr to Allah SWT.

\section{Understanding Patience}

Etymologically patient "Ash Shabr" means to restrain and restrain "Al HabsWa $\mathrm{Al}$ Kuf". Terminologically patience means refraining from everything that is not liked because it expects the pleasure of Allah. ${ }^{25}$ Terminologically, patience means refraining from everything because you expect the pleasure of Allah SWT. Be patient when you get a disaster and be patient when you are in things you like. In this case it can be said that patience refrains from lust.

Hujjatul Islam Imam Al-Ghazali stated that patience is keeping the religious impulses up against the impulses of lust. With religion, Allah guides humans to know Him, know His Messenger and know and practice His teachings and the benefits associated with the consequences. ${ }^{26}$

According to M. Quraish Shihab, patience means refraining or limiting the soul from its desires in order to achieve something good. Accompanied by other opinions, it is also said that patience means refraining from feeling restless, anxious and angry. ${ }^{27}$ From the above definition, it is explained that patience is an encouragement of Islam to its people to always be patient when they have problems and must always be patient when they are happy. Because by being patient we can restrain our hearts and restrain our passions from the desires of human nature and the invitation of lust. ${ }^{28}$

Literally patient means steadfast. According to Ali bin Abi Talib that patience is part of faith as the head has a higher position than the body. This shows that patience plays an important role in human life. ${ }^{29}$ Patience is to endure suffering, not to complain, not to be restless and not to complain and moan, when tests and trials come from Allah SWT. People who have reason are those who are patient in facing all kinds of difficulties and obstacles and dare to sacrifice their souls to get rid of anything that hinders their efforts and do not step back in order to achieve their goals. ${ }^{30}$

How important it is for every human being to have patience in every situation and condition in Islam has taught its people to decorate themselves with patience. Because patience has great benefits in training yourself and with patience it will also increase human istiqomah in facing problems and tests in life. ${ }^{31}$

Generally, scholars divide patience into three types, namely: 1) Be patient in carrying out obedience to Allah. 2) Be patient not to do things that Allah has forbidden. 3) Be patient in the face of God's destiny, namely various painful things and disturbances that arise beyond human control or from other people. ${ }^{32}$

\footnotetext{
${ }^{27}$ Sukino, "The Concept of Patience in the Qur'an and Its Contextualization in the Purpose of Human Life Through Education," Rubama Journal Vol 1 No 1 (2018): 66.

28 Abbudin Nata, Sufism and Noble Character (Jakarta: PT Raja GrafindoPersada, 2013), 173-74.

${ }^{29}$ Mahyuddin Ibrahim, Disgraceful and Praisewortby Nature (Yogyakarta: Restu Agung, 2000), 124.

${ }^{30}$ Ernadewita, "Patience as Mental Health Therapy," Journal of Studies and Development 13 (2019): 51.

31 Ernadewita, 51.

32 M. Imam Pamungkas, Modern Muslim Morals Building the Character of the Young Generation (Bandung: Marja, 2012), 74.
}

41.

${ }^{25}$ Yunahar Ilyas, Morals Lecture (Yogyakarta: Offset Student Library, 2011), 134.

${ }^{26}$ Zulhammi, "Patient Behavior Relevance to Mental Health" Darul Ilmi Journal Vol 04, No 01 (2016): 
Meanwhile, according to the Qur'an, the scope of application of patience includes the following: 1) In terms of worship, 2) In the face of ridicule and slander of disbelievers, 3) In the face of calamity, 4) In waiting for Allah's decree, 5) In waiting for God's promise, 6) In obtaining all needs, 7) In order to gain multiple powers. ${ }^{33}$

Patience in the Qur'an contains an element of action, meaning that patience is an attitude or action that encourages good for Muslims. This is so that a person has motivation in doing charity as well as self-resistance and fortitude in the face of calamities and various difficulties.

Patience is a part of the main character needed by a Muslim in matters of the world and religion and he must base all kinds of deeds and ideals on him. As a Muslim, it is obligatory to strengthen his heart to endure all trials and tribulations calmly. Patience makes a person more diligent in making plans and patiently fortifies all hasty and patient decisions that will also control anger. Patience is a person's resilience in the face of all trials and calamities without the slightest change in him

People who have reason are those who are patient in facing all kinds of difficulties and obstacles and dare to sacrifice their souls to get rid of anything that gets in the way of their efforts, not even giving up in order to achieve their goals. ${ }^{34}$

It has become a necessity for humans to be patient and always persevere and not stand idly by when they are being tried with a disaster. This is so that he belongs to the group of people who keep their promises and carry out their obligations. ${ }^{35}$

A person who believes will be patient in the face of calamities and trials given by Allah SWT. Someone who is patient will get a reward from Allah SWT because behind every calamity and test given is a great gift that Allah has prepared for all his people. Therefore, in many verses Allah commands to be patient. In fact, Allah ordered to make patience and prayer as a means to ask Him. Allah also ordered to exemplify the patience of the Apostles of Ulul Azmi there are five namely Noah, Ibrahim, Moses, Isa and Muhammad SAW. They are the Apostles who have reached a very high level of patience. Ulul Azmi means people who have a strong determination. ${ }^{36}$

\section{Kinds of Patience}

According to Yusuf Al-Qardawi in his book Al-Qardawi in his book Ash-Shabr AlQur'an, patience is divided into six kinds:

Patiently Accepting Life's Trials.; The trials of life, both physical and non-physical, will befall everyone in the form of hunger, thirst, pain, fear, loss of loved ones, loss of property and so on.

Patience from the Desire of Lust. Lust wants all kinds of pleasures of life, pleasures and splendor of the world. To control all these desires requires patience. Don't let all the pleasures of life in this world make someone forget themselves, let alone forget God.

Patience in obedience to Allah SWT: In obeying Allah's commands, especially in worshiping him, patience is needed. Patience in Preaching; The path of da'wah is a long winding road full of trials. A person who goes through that path must have patience. Patience in $W$ ar, In war, patience is needed especially when facing more or stronger enemies. Among the qualities of a pious person is patience in war.

\footnotetext{
33 Imam Pamungkas, 73-77.

${ }^{34}$ K. H. Abdullah Zakiy Al-Kaaf, Forming Morals (Bandung: CV PustakaSetia, 2001), 19.

${ }^{35}$ Ibnu Taimiyah, Heart Practice (DKI Jakarta: Cendikia, 2003), 85.

${ }^{36}$ Umar Muhammad Abu Bakr, The Power of Sincerity, Patience, Qana'ah (Surakarta: Ziyad Vision Media,
} 2012), 75 . 
In the association between human beings, whether between husband and wife, between parents and children, between neighbors and neighbors, between teachers and students, or in the wider community, things will be found that are unpleasant or offensive. ${ }^{37}$ Therefore, in everyday life, patience is needed so that you don't get angry or break relationships when you encounter things you don't like.

\section{The Miracle of Patience}

Patience is truly magical and has been proven in the lives of many people. A successful student also goes through periods of struggle in learning and pursuing his education. If we pay attention to the life stories of successful people, we will find their lives full of tenacity and hard work for a long time. Because there is no success that comes without effort in earnest. ${ }^{38}$

From this patience, various other commendable qualities were born, patience is the engine of moral production. Patience to respect time will give birth to discipline, patience to put things in their place according to their arrangement gives birth to neatness and order, patience in working hard and diligently gives birth to tenacity and tenacity, patience to maintain an attitude, do good to others, always smile and always reach out to give birth friendliness and courtesy. ${ }^{39}$

Based on the above definition, everyone should have patience because with the patient nature we will be respected by many people. Not only in everyday life in the world of education, we should always be patient in facing various problems and obstacles, believe that patience has very good miracles.

\section{The Essence of the Importance of Patience}

In carrying out this patience there are three things involved at once, namely, the heart, tongue and limbs. A person is called patient if he can hold his heart from complaining and anger, holding his tongue from complaining and holding his limbs from doing bad things. Patience is a noble character that prevents oneself from doing inappropriate things. It is a power that gives a special touch to the soul so that it can provide determination in times of shock. ${ }^{40}$

Patience must be possessed by every individual to achieve success in this world and the hereafter because patience is a very noble and special trait. With their patient nature they will get a reward in the hereafter because of their patience.

The scholars divide patience into three:

Be patient in obedience: In a day and a night we get orders to perform the five daily prayers. This obligation must be carried out throughout the ages until the time of death. In this condition our patience is tested whether we will carry out Allah's commands on time. On the other hand, when someone is negligent and impatient, then silence allows himself to be in the devil's conclusion.

Be patient to leave disobedience; Not only when carrying out orders, we are also asked to be patient when dealing with disobedience. This is usually more severe than the first because, we are asked to leave the things that the soul likes. In such a situation comes the commandment to be patient to restrain desire and limit lustful desires. So patience to refrain from this disobedience becomes part of jihad. It becomes an extraordinary worship and can elevate someone to a higher level.

\footnotetext{
${ }^{37}$ Yunahar Ilyas, Morals Lecture (Yogyakarta: Offset Student Library, 2011), 134-137.

38 Umar Al-Faruq, The Power of Sincerity, t.t., 80.

39 Al-Faruq, 81.

${ }^{40}$ Muhammad Abu Bakr, The Power of Sincerity, Patience, Qana'ah, 71-72.
} 
Patience in the face of adversity: It is impossible to hope to live without problems, because this world's model of life is a place of trials and tribulations. The ordeal can be illness, lack of wealth, lack of food or the death of someone we love. ${ }^{41}$

So the severity of the patient's character, so it is a special quality that can only be done for people who are humble '. And it is those who are humble 'who really have strong beliefs, sincere intentions, good determination, right goals and with patience they obey religious regulations in the form of orders or prohibitions with a sense of moral obligation in carrying out and completing them. ${ }^{42}$

Patience is not only needed when you get a disaster, but patience is also needed to appreciate the time that will give birth to discipline. With patience, we will maintain our attitude and do good to others, always smile and always reach out to success.

The Qur'an describes several ways to cultivate patience. 1) Instilling the belief that there is a good reward for those who are patient because this is something that is very important in helping someone to have a patient nature. Abu Talib al-Makky said that the main cause of a person's lack of patience is the lack of belief in a good reward for those who are patient. 2) Reminding that people who are closest to Allah such as the Prophets and Apostles always get trials even though the trials are more severe than most humans. 3) Instilling confidence in the existence of ease after hardship and the promises of Allah as a certainty. 4) Instilling the awareness that humans belong to God, he is the one who gives life, feeling, motion, hearing, heart and vision. 5) Given the sunatullah or laws that apply in the world. 5) Instilling belief in the unavoidable Qada and Qadar of Allah. ${ }^{43}$

\section{The Benefits of Patient Education}

Believers never forget that Allah SWT has created humans with many conditions and situations such as sad, happy and happy. The purpose of creating these conditions and situations is for humans to use their minds to solve a problem in a way that is favored by Allah SWT. When they cannot solve the problem on their own, all they have to do is be patient and believe that Allah's help will come. ${ }^{44}$

So important is patience in living life in the world so that Allah SWT and His Messenger provide the benefits and virtues of patience, namely: 1) Getting What You Want. 2) Becoming a People Leader, 3) Getting Allah's Help; That the main capital to obtain help from Allah SWT is victory that is easily achieved with patience as has been explained in the previous verse that Allah SWT has ordered Muslims to be patient in the face of hate and revenge. If the Muslims are able to be patient and pious then surely the tricks of the polytheists will not harm them.

Gaining High Degrees in Heaven: Hamka explained that people who are patient will be given a noble place, a beautiful room or room, a special room in heaven because people who walk in upholding the truth will become obedient and obedient servants and always be patient. Therefore they deserve the happiness of the soul, occupy Jannatunna'im paradise and a peaceful place to live.

Get Unlimited Rewards: Hamka explained that the tool to obtain divine guidance that will bring him happiness in the world and the hereafter is patience and steadfastness. Because only those who are patient will arrive at what is the goal, which is to get a double reward with Allah SWT. ${ }^{45}$

\footnotetext{
${ }^{41}$ Muhammad Abu Bakr, 83-87.

42 Zahri Mustofa, Key to Understanding Sufism (Surabaya: PT BinaIlmu, 2000), 68.

${ }^{43}$ M. Yusuf et al, "Patience in Islamic and Western Perspectives," Al-Murabbi, no. 4 (2018): 238-39.

${ }^{44}$ Raihanah, "The Concept of Patience in the Qur'an" 6, no. 1 (2016): 481.

45 Raihanah, 484.
} 


\section{The Wisdom of Patience}

Al-Quran is the holy book of Muslims which contains the revelation of Allah SWT which was revealed to the Prophet Muhammad SAW. The Qur'an is a holy book that contains various things needed by mankind and the main purpose of the Qur'an being revealed is to be a guide for human life in carrying out life in order to get happiness in the world and the hereafter. Every Muslim is aware that the Qur'an is a holy book which is a guide to life and the basis of every step of life and the Qur'an not only regulates human relations with their Lord but also regulates human relations with humans for the happiness of life in this world and the hereafter. ${ }^{46}$

There are several lessons that we can take from patient behavior, namely: 1) Able to carry out every command and stay away from religious prohibitions properly. If there is no patience in a person, then in every difficulty and calamity faced in carrying out religious orders, there will be feelings of complaint, loss of enthusiasm and easily despair. 2) Make the mind more mature. If lust has mastered the mind and cannot think in the face of problems, all the behavior that is done is only following the desires of lust. 3) Makes the heart calmer and happier. Noot because of wealth or being but, he was satisfied with what was already in him. Patiently accept what Allah SWT has given him. 4) Make every worship more perfect. Patience when praying makes it solemn, while fasting, patience makes the perfection of worship both in terms and pillars. At the time of performing the pilgrimage will be more aware of the purpose and guidance to keep away from immorality and sin, pitting against each other, looking for names and ranks and not being vindictive.

Get the reward according to the level; Patience, this word is repeated in the Qur'an more than 70 places. In these verses it can be seen that Allah SWT bestows people who have patience with various virtues, various virtues and honorable degrees that He promises as the fruit of their attitude. commendable.

Patience brings luck. We are commanded by Allah SWT to be patient in order to obtain happiness in life both in this world and in the hereafter. With an attitude of patience and istiqomah carried out by believers in Allah SWT, it will certainly produce encouraging fruit. Patience means strengthening personality. Someone who is patient will certainly not be too sad when a disaster or trial is struck, will not be weak when facing a problem or problem. They will understand that all of this is a trial from Allah SWT.

Based on the quote that the author has described that the greatness of Allah SW'T and those who are patient is a reward that cannot be counted because patience will bring victory. Allah SWT gives blessings, mercy and guidance to those who are patient.

\section{CONCLUSION}

In living life, it is very important to have patience because patience is one of the characteristics of piety to Allah SWT because patience is part of faith. In living life, it will not go smoothly as expected, there must be problems and tests that must be faced by being patient. As for the benefits of someone who has a patient nature, namely getting help from Allah SWT, the reward will be doubled, the heart will be calmer and happier. Therefore, keep having patience because patience is actually a medicine for the heart, with patience it will make a better person and avoid things that are not liked by Allah SWT. The wisdom of patient education is to make every worship more perfect and to be able to carry out every command and stay away from its prohibitions (2018): 201

${ }^{46}$ Ulfa Muaziroh, "Actualization of the Concept of Patience in the Perspective of the Qur'an" 03 


\section{REFERENCES}

Achmadi. Ideology of Islamic Education. Yogyakarta: Pustaka Pelajar, 2005.

Al-Faruq, Umar. The Power of Sincerity, t.t.

Ardy Wijaya, Novan. Faith and Taqwa-Based Character Education. Yogyakarta: : Teras, 2012.

Assegaf, Rachman. School of Islamic Education Thought. depok: PT Raja Grafindo, 2013.

Azizah, Mar'atul, dan Miranda Nur Apdila. "Peran Kepala Madrasah Sebagai Supervisor Dalam Peningkatan Kinerja Guru." Chalim Journal of Teaching and Learning (CJoTL) 1, no. 1 (24 Agustus 2021): 73-84.

Basri, Hasan. Philosophy of Islamic Education. Bandung: Pustaka Setia, 2009.

Daradjat, Zakiah. Islamic Education. Jakarta: Bumi Aksara, 1996.

Ernadewita. "Patience as Mental Health Therapy." Journal of Studies and Development 13 (2019): 01.

Haydar Putra, Daulay. Islamic Education in the National Education System in Indonesia. Kencana Prenada Media Group, 2004.

Ibn Rush, Abidin. Al-Ghazali's Thoughts on Education. Yogyakarta: Student Library, 2009.

Ibrahim, Mahyuddin. Disgraceful and Praiseworthy Nature. Yogyakarta: Restu Agung, 2000.

Ilyas, Yunahar. Morals Lecture. Yogyakarta: Offset Student Library, 2011.

Imam Pamungkas, M. Modern Muslim Morals Building the Character of the Young Generation. Bandung: Marja, 2012.

Khosyi'in, Ahmad. "Peran Kepemimpinan Kepala Sekolah, Pengambilan Keputusan, Dan Budaya Organisasi Terhadap Disiplin Kerja." Chalim Journal of Teaching and Learning (CJoTL) 1, no. 1 (7 Agustus 2021): 45-55.

Kurniawan, Syamsul. Philosophy of Islamic Education. malang: Madani, 2017.

Langgulung, Hasan. Principles of Islamic Education. Jakarta: PT Pustaka Al Husna Baru, 2003.

Mahfud, Agus. Islamic Education. depok: Nadi Pustaka, 2012.

Muaziroh, Ulfa. "Actualization of the Concept of Patience in the Perspective of the Qur'an" 03 (2018): 02.

Muhammad Abu Bakr, Umar. The Power of Sincerity, Patience, Qana'ah. Surakarta: Ziyad Vision Media, 2012.

Mukani. Dynamics of Islamic Education. Yogyakarta: Madani, 2016.

Muslihan, Hj. Eneng. islamic education. Jakarta: Diadit Media, 2011.

Mustofa, Zahri. Key to Understanding Sufism. Surabaya: PT Binallmu, 2000.

Nata, Abbudin. Paradigm of Islamic Education. Jakarta: PT Grasindo, 21.

Sufism and Noble Character. Jakarta: PT Raja GrafindoPersada, 2013.

Ngatini dan, Lestari. Contextual Islamic Education. Yogyakarta: Pustaka Pelajar, 2010.

Nizar, Samsul. Introduction to the Fundamentals of Islamic Education Thought. Jakarta: Gaya Media Pratama, 2001.

Nurkholis. "Education in Efforts to Advance Technology." Journal of Education Vol 1, No 1 (2013).

Raihanah. "The Concept of Patience in the Qur'an" 6, no. 1 (2016).

Sadulloh, Uyoh. Educational Science Pedagogy. Bandung: AlFABETA, 2011. 
Siti Sholichah, Aas. Educational Theories in Islam. No 1. Vol. 07. Jakarta: , Islamic Education, 2017.

Sudibyo, Bambang. RI Law No. 20 of 2003 concerning National Education System and RI Government Regulation No. 47 of 2008 concerning Compulsory Education. Bandung: Citra Umbara, 2008.

Sukino. "The Concept of Patience in the Qur'an and Its Contextualization in the Purpose of Human Life Through Education.” Ruhama Journal Vol 1 No 1 (2018).

Taimiyah, Ibnu. Heart Practice. DKI Jakarta: Cendikia, 2003.

Widy, Adi. "Functions and Goals of Indonesian Education" Journal of Basic Education Vol 4 No 1 (2019): 31.

Yusuf et al, M. "Patience in Islamic and Western Perspectives." Al-Murabbi, no. 4 (2018): 02.

Zakiy Al-Kaaf, K. H. Abdullah. Forming Morals. Bandung: CV PustakaSetia, 2001.

Zed, Mestika Zed. Literature Research Methods. Jakarta: Indonesia Obor Foundation, 2008.

Zulhammi. "Patient Behavior Relevance to Mental Health" Darul Ilmi Journal Vol 04, No 01 (2016). 